\title{
Is the segmental wall motion predictor of quality of life changes two years after coronary artery by-pass surgery?
}

\author{
V Peric $^{1 *}$, S Sovtic ${ }^{1}$, A Jovanovic ${ }^{1}$, R Stolic ${ }^{1}$, S Lazic ${ }^{1}$, Z Marcetic ${ }^{1}$, D Djikic ${ }^{1}$, P Otasevic ${ }^{2}$ \\ From 23rd World Congress of the World Society of Cardio-Thoracic Surgeons \\ Split, Croatia. 12-15 September 2013
}

\section{Background}

The advantage in predictive value of coronary artery bypass surgery (CABG), as the therapeutic treatment in patients with coronary artery disease with low left ventricle ejection fraction $(E F)$ is well known. Influence of abnormal segmental wall motion on the reduction of EF is well known. However, it is not quite clear, what is the relation between abnormal segmental wall motion and quality of life (QOL) after CABG.

\section{Methods}

We administered the Nottingham Health Profile Questionnaire part I in a consecutive series of patients (243 pts, 195 men) who underwent elective CABG. The questionnaire was distributed before and two years after CABG, to all patients. EF was determined by echocardiography, after Simpson method. Segmental wall motion was determined by echocardiography and ventriculography.

\section{Results}

Preoperatively, abnormal segmental wall motion was found in $188(77 \%)$ patients, and normal at $55(23 \%)$ patients. Patients with abnormal segmental wall motion had significantly the lower EF $(52.89 \pm 8.11$ vs. $40.94 \pm$ 10.93, $\mathrm{p}<0.001)$. After CABG, QOL was significantly improved in both examined groups $(\mathrm{p}<0,01)$. There was no significant correlation between the amount of QOL changes two years after CABG and segmental wall motion $(p>0,05)$. Univariate and multivariate logistic regression showed that abnormal segmental wall motion was not the

\footnotetext{
* Correspondence: pericvladan@yahoo.com

'University of Pristina, School of Medicine, Internal Clinic, Kosovska Mitrovica, Serbia

Full list of author information is available at the end of the article
}

independent predictor of the patients improved or worsened by operation.

\section{Conclusions}

Two years after CABG, QOL was significantly improved and that improvement was not related to segmental wall motion. Abnormal segmental wall motion was not the predictor of QOL changes two years after CABG.

\section{Authors' details}

'University of Pristina, School of Medicine, Internal Clinic, Kosovska Mitrovica, Serbia. ${ }^{2}$ Dedinje Cardiovascular Institute, Belgrade, Serbia.

Published: 11 September 2013

doi:10.1186/1749-8090-8-S1-P81

Cite this article as: Peric et al:: Is the segmental wall motion predictor of quality of life changes two years after coronary artery by-pass surgery? Journal of Cardiothoracic Surgery 2013 8(Suppl 1):P81.

Submit your next manuscript to BioMed Central and take full advantage of:

- Convenient online submission

- Thorough peer review

- No space constraints or color figure charges

- Immediate publication on acceptance

- Inclusion in PubMed, CAS, Scopus and Google Scholar

- Research which is freely available for redistribution

Submit your manuscript at www.biomedcentral.com/submit
C Biomed Central

\section{Biomed Central}

(c) 2013 Peric et al; licensee BioMed Central Ltd. This is an Open Access article distributed under the terms of the Creative Commons Attribution License (http://creativecommons.org/licenses/by/2.0), which permits unrestricted use, distribution, and reproduction in any medium, provided the original work is properly cited. 